ZOOLOGIA 32 (1): 9-13, February 2015

http://dx.doi.org/10.1590/S1984-46702015000100002

\title{
Anuran community composition along two large rivers in a tropical disturbed landscape
}

\author{
Mauricio Almeida-Gomes ${ }^{1,3}$, Carlos Frederico Duarte Rocha ${ }^{2} \&$ Marcus Vinícius Vieira ${ }^{1}$
}

\author{
'Departamento de Ecologia, Universidade Federal do Rio de Janeiro. Avenida Carlos Chagas Filho 373, Cidade Universitária, \\ 21941-902 Rio de Janeiro, RJ, Brazil. \\ ${ }^{2}$ Departamento de Ecologia, Universidade do Estado do Rio de Janeiro. Rua São Francisco Xavier 524, 20550-900 Rio de \\ Janeiro, RJ, Brazil. \\ ${ }^{3}$ Corresponding author. E-mail: almeida.gomes@yahoo.com.br
}

\begin{abstract}
In this study we evaluated how anuran species were distributed in riparian habitats along two large rivers. Sampling was carried out between January and March 2012 in the municipality of Cachoeiras de Macacu, state of Rio de Janeiro. We delimited 20 plots along each river, ten in portions inside the forest of the Reserva Ecológica de Guapiaçu (REGUA), and with comparatively greater amount of forest cover, and ten outside REGUA, with comparatively lesser forest cover surrounding the rivers. We recorded 70 individuals from 14 frog species in the Manoel Alexandre River and 63 individuals from 15 frog species in the Guapiaçu River. The most abundant species in both rivers was Cycloramphus brasiliensis (Steindachner, 1864), and it was more abundant in sections with greater amount of forest cover. This information, coupled with the occurrence of species that are more adapted to open and more disturbed habitats in river sections that harbor lesser riparian vegetation, help to explain differences in amphibian species composition between river sections with greater and lesser forest cover. The results of our study highlight the importance of preserving riparian vegetation associated with rivers in the Atlantic Forest for the conservation of amphibians.
\end{abstract}

KEY WORDS. Amphibian conservation; aquatic environments; connectivity; frog species; riparian forests.

Land-use change represents a serious threat to amphibians, and poses a challenge for their conservation (Hof et al. 2011). Local amphibian communities can be structured by several factors, some of which are affected by land use. Examples are the size of forest fragments (Bell \& Donnelly 2006), the presence of suitable reproductive sites (ZIMMERMAN \& BIERREGAARD 1986), and the presence of riparian vegetation (PARRIS \& MCCARTHY 1999). Riparian habitats can be important for maintaining the structural and physicochemical characteristics of aquatic environments, hence they are important factors determining community composition in these habitats (Gomi et al. 2006). In fact, anuran assemblages are frequently structured along a continuum of riparian habitats (e.g., Keller et al. 2009, Rodríguez-Mendoza \& Pineda 2010), which can be crucial for vulnerable amphibian species in tropical forest areas. Besides, riparian habitats provide connectivity between forest patches and facilitate gene flow between amphibian populations (RICHARDS-ZaWACKI 2009). Since many amphibian species depend on these environments for reproduction (HADDAD \& Prado 2005), and some of them live all their life cycles closely associated with water bodies that are near riparian vegetation, preservation of the latter may be critical to the viability of several species (Ficetola et al. 2009, Todd et al. 2009).
The Atlantic Forest has high biodiversity and endemism, being among the five most threatened biomes in the world (Mittermeier et al. 2005). However, despite the fact that human interference has reduced the Atlantic Forest to about $12 \%$ of its original area (Ribeiro et al. 2009), it still harbors more than 480 amphibian species. Most of these species have an aquatic larval phase (BЕскER et al. 2007). Since the mid 2010s there has been an intense discussion in Brazil regarding a review of the current Brazilian Forest Act (Metzger et al. 2010). Among the most controversial points of this review is the proposed reduction of the minimum width of riparian vegetation in each property, which can result in serious consequences for the persistence of many amphibian species. This situation is worsened by the fact that even under the current legislation the protection area of riparian vegetation has not been enforced (BECKER et al. 2007). In this context, it is urgent to gather field data to evaluate the importance of riparian vegetation for amphibian species and local communities. It is still unknown how riparian forest loss affects anuran communities in Atlantic Forest rivers. The aim of this study was to compare anuran species composition in riparian habitats of two rivers with different amounts of forest cover (greater and lesser forest cover). We expected that community composition would differ be-

2015 | Sociedade Brasileira de Zoologia | www.sbzoologia.org.br | www.scielo.br/zool All content of the journal, except where identified, is licensed under a Creative Commons attribution-type BY-NC. 
tween plots with greater and lesser riparian forest cover: those with more deforested plots were expected to harbor more generalist species than plots with greater forest cover, which were expected to be mostly occupied by anuran species that are strictly adapted to forests.

\section{MATERIAL AND METHODS}

We conducted this study between January and March 2012 in the Reserva Ecológica de Guapiaçu, REGUA $\left(22^{\circ} 24^{\prime} \mathrm{S}\right.$, $42^{\circ} 44^{\prime} \mathrm{W}$ ), in the municipality of Cachoeiras de Macacu, state of Rio de Janeiro, Brazil. REGUA is a private reserve comprising about 7,600 ha of Atlantic forest, most of which is continuous with the large forest patch of the Serra dos Órgãos mountain range (AlmeIDA-Gomes \& Rocha 2014). Sampling was carried out in two rivers, Manoel Alexandre and Guapiaçu (Figs. 1-3). Both rivers have a gradient of riparian forest cover: the portions of rivers inside REGUA have greater forest cover, which progressively reduces as the rivers leave REGUA. Rivers outside REGUA have little riparian vegetation surrounded mostly by pasture areas. A total of 20 plots, each $20 \mathrm{~m}$ in length were delimited along each river, 10 inside and 10 outside REGUA, totaling 400 $\mathrm{m}$ sampled in each river. Each plot ranged from one margin of the river to the other, and was separated from the nearest plot by at least $10 \mathrm{~m}$. To limit altitudinal variation, the maximum difference in altitude between upstream and downstream plots was approximately $100 \mathrm{~m}$ at the Manoel Alexandre River(108$220 \mathrm{~m})$, and $60 \mathrm{~m}$ at the Guapiaçu River (39-98 m).

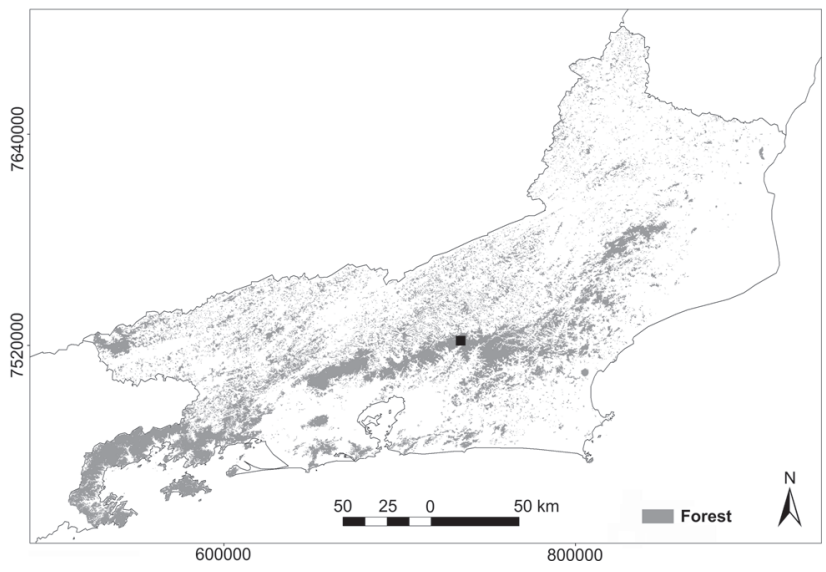

Figure 1. Location of Reserva Ecológica de Guapiaçu (REGUA, black square) in the state of Rio de Janeiro.

We conducted visual encounter surveys, VES (CRump \& Sсотт 1994) at nighttime (19:00 to 23:00 h) using headlamps. We conducted VES within each plot up to five meters distance from the water and along the entire river channel (Fig. 4), with a sampling effort of two hours in each plot. The total sampling

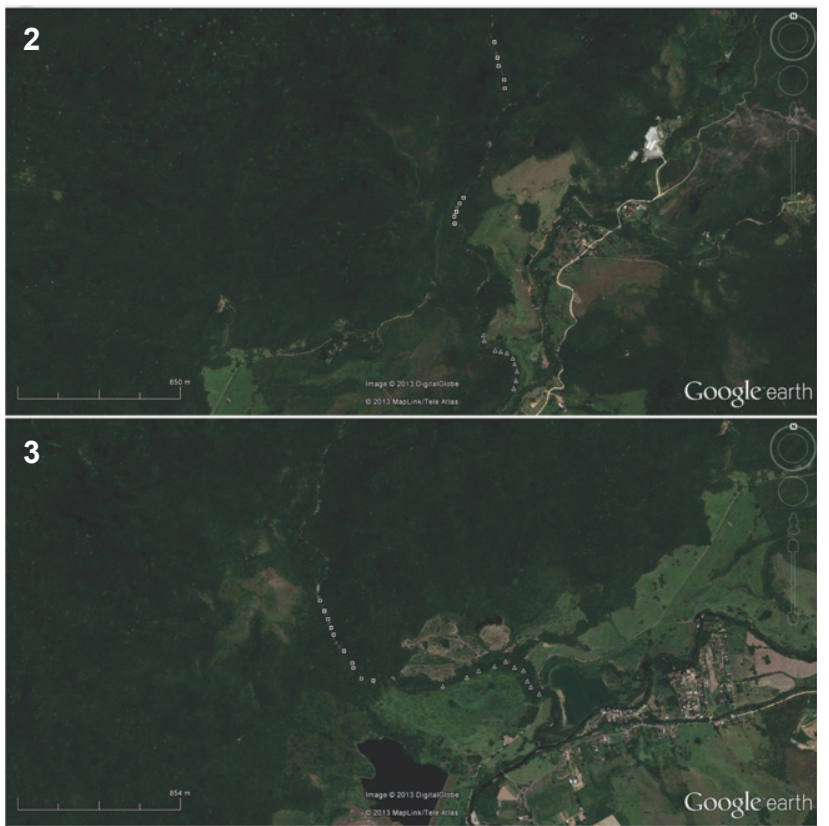

Figures 2-3. Study area indicating the location of plots along the Manoel Alexandre (2) and Guapiaçu (3) rivers, municipality of Cachoeiras de Macacu, state of Rio de Janeiro, Brazil. (squares) Plots with greater forest cover, (triangles) plots with lesser forest cover.

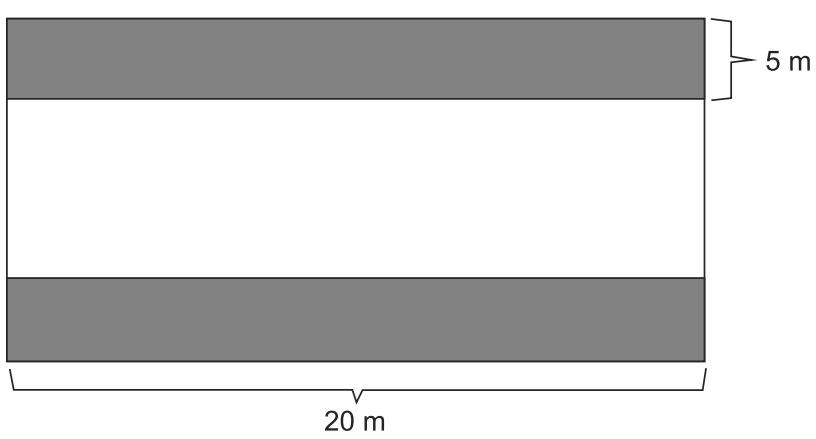

Figure 4. A river plot showing the total sampled area for anurans, including margins (gray) and river channel (white).

effort at each river was 40 hours of nocturnal active search. Each individual was identified to species and then released at the same point it was originally captured. To evaluate the ordination of plots regarding amphibian species composition and abundance pooled for both rivers, we used a two-axis Non-Metric Multidimensional Scaling, NMDS, on a matrix of Bray-Curtis dissimilarity distances between plots (Legendre \& Legendre 1998). The two NMDS axes were used as dependent variables in a factorial multivariate analysis of variance (MANOVA) using Wilks' $\lambda$ to test if community composition represented by the two NMDS axes differs with respect to the rivers, riparian forest cover (lesser 
or greater), or an interaction of both (BÁEz et al. 2012). We conducted all analyzes in the R environment (version 2.13.0, R Development Core Team 2011).

\section{RESULTS}

We recorded a total of 133 individuals from 22 anuran species at both rivers. The most abundant species were Cycloramphus brasiliensis (Steindachner, 1864) $(33.8 \%$ of all individuals), Rhinella ornata (Spix, 1824) $(16.5 \%)$, and Leptodactylus latrans (Steffen, 1815) (12.8\%) (Table I). In the Manoel Alexandre River, 70 individuals were recorded from 14 frog species, ten species $(\mathrm{N}=39)$ in plots with higher forest cover, six $(60 \%)$ only in these portions of the river. In plots with lower forest cover, eight species were recorded $(\mathrm{N}=31)$, four (50\%) only in these portions of the river. The most abundant species in the Manoel Alexandre River was C. brasiliensis, $48.7 \%$ in greater forest cover plots, $32.2 \%$ in lesser forest cover plots. In the Guapiaçu River, 63 individuals were recorded from 15 frog species, eight species $(\mathrm{N}=31)$ in plots with greater forest cover, four $(50 \%)$ exclusively in these portions of the river. In plots with lesser forest cover, 11 species were recorded $(\mathrm{N}=32)$, seven of them $(63.6 \%)$ exclusively in these portions of the river. The most abundant species in greater cover plots of the Guapiaçu River was also C. brasiliensis (48.4\%), but in lesser cover plots $L$. latrans was the most abundant (37.5\%).

The ordination of amphibian species composition and abundance (Stress $=0.124$ ) showed that most plots with comparatively greater forest cover clustered together (Fig. 5). Conversely, the plots with lesser forest cover were more scattered

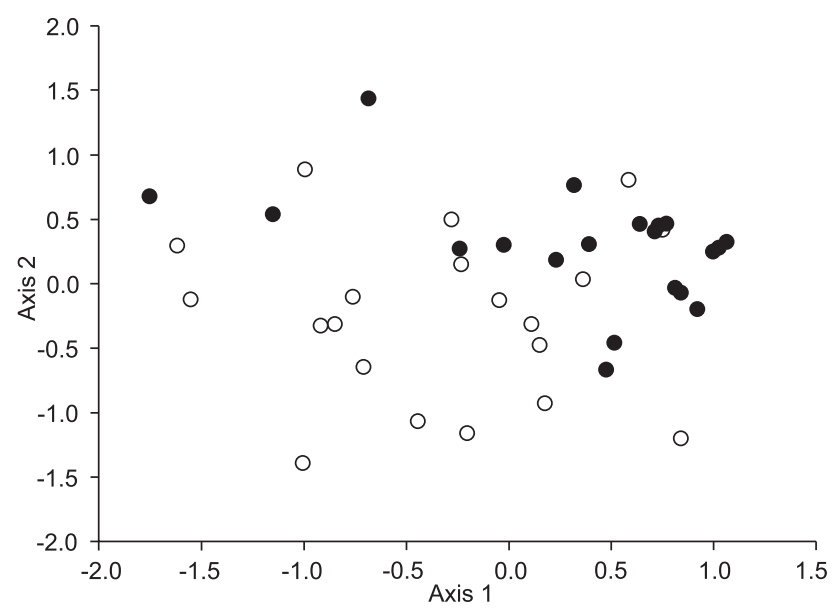

Figure 5. Ordination of sampling plots along the axes of Nonmetric Multidimensional Scaling (NMDS) of anuran species composition and abundances in two large rivers in the municipality of Cachoeiras de Macacu, state of Rio de Janeiro, Brazil. Black circles are plots with greater riparian forest cover, and white circles represent plots with lesser riparian forest cover.
Table I. Number of individuals of amphibian species recorded during Visual Encounter Surveys in two rivers with high and low forest cover portions in the municipality of Cachoeiras de Macacu, state of Rio de Janeiro, Brazil.

\begin{tabular}{|c|c|c|c|c|c|c|}
\hline \multirow[b]{3}{*}{ Brachycepahlidae } & \multicolumn{3}{|c|}{$\begin{array}{l}\text { Manoel Alexandre } \\
\text { River }\end{array}$} & \multicolumn{3}{|c|}{ Guapiaçu River } \\
\hline & \multicolumn{3}{|c|}{ Greater Lesser Total } & \multirow[t]{2}{*}{ Greater } & \multirow[t]{2}{*}{ Lesser } & \multirow[t]{2}{*}{ Total } \\
\hline & & & & & & \\
\hline Ischnocnema guentheri & 0 & 0 & 0 & 1 & 0 & 1 \\
\hline \multicolumn{7}{|l|}{ Bufonidae } \\
\hline Rhinella icterica & 2 & 0 & 2 & 0 & 0 & 0 \\
\hline Rhinella ornata & 4 & 5 & 9 & 3 & 10 & 13 \\
\hline \multicolumn{7}{|l|}{ Craugastoridae } \\
\hline Haddadus binotatus & 1 & 0 & 1 & 0 & 0 & 0 \\
\hline \multicolumn{7}{|l|}{ Cycloramphidae } \\
\hline Cycloramphus brasiliensis* & 19 & 10 & 29 & 15 & 1 & 16 \\
\hline \multicolumn{7}{|l|}{ Hylidae } \\
\hline Dendropsophus anceps & 0 & 0 & 0 & 0 & 1 & 1 \\
\hline Dendropsophus berthalutzae & 0 & 0 & 0 & 0 & 1 & 1 \\
\hline Hypsiboas albomarginatus & 0 & 1 & 1 & 1 & 0 & 1 \\
\hline Hypsiboas faber & 0 & 4 & 4 & 0 & 0 & 0 \\
\hline Hypsiboas secedens* & 2 & 0 & 2 & 0 & 0 & 0 \\
\hline Hypsiboas semilineatus & 0 & 0 & 0 & 0 & 1 & 1 \\
\hline Scinax albicans* & 6 & 3 & 9 & 6 & 0 & 6 \\
\hline Scinax alter & 0 & 3 & 3 & 0 & 0 & 0 \\
\hline Scinax humilis* & 1 & 2 & 3 & 0 & 1 & 1 \\
\hline Scinax v-signatus* & 1 & 0 & 1 & 0 & 0 & 0 \\
\hline Scinax aff. $x$-signatus & 1 & 0 & 1 & 0 & 0 & 0 \\
\hline Trachycephalus mesophaeus & 0 & 0 & 0 & 2 & 1 & 3 \\
\hline \multicolumn{7}{|l|}{ Leptodactylidae } \\
\hline Adenomera cf. bokermanni & 0 & 0 & 0 & 0 & 1 & 1 \\
\hline Leptodactylus latrans & 0 & 3 & 3 & 2 & 12 & 14 \\
\hline Leptodactylus spixi & 0 & 0 & 0 & 0 & 1 & 1 \\
\hline Physalaemus signifer & 2 & 0 & 2 & 1 & 0 & 1 \\
\hline \multicolumn{7}{|l|}{ Microhylidae } \\
\hline Stereocyclops parkeri & 0 & 0 & 0 & 0 & 2 & 2 \\
\hline
\end{tabular}

* Species endemic to state of Rio de Janeiro.

in the ordination biplot. The difference in species composition was nearly significant between rivers (MANOVA: Wilks' $\lambda$ $\left.=0.871, \mathrm{~F}_{1,36}=2.589, \mathrm{p}=0.089\right)$, but differences were significant between plots with different forest cover (Wilks' $\lambda=0.619$, $\left.\mathrm{F}_{1,36}=10.764, \mathrm{p}<0.001\right)$, and for the interaction between rivers and forest cover (Wilks' $\lambda=0.821, \mathrm{~F}_{1,36}=3.811 ; \mathrm{p}=0.032$ ).

\section{DISCUSSION}

The results indicate that riparian habitats are extremely important for amphibian conservation since they maintain 
high species richness and abundance of frogs in spite of the relatively small area occupied by riparian forests. These specific environments may also provide more realistic assessments of extinction threats faced by stream-dwelling amphibians in the Atlantic Forest and other biomes (Almeida-Gomes et al. 2014a). In a 10-year survey in the same region,(ALMEIDA-GomES et al. 2014b), 73 amphibian species were registered, 10 of which are endemic to the state of Rio de Janeiro. The present study was comparatively shorter, yet it found one third of the species recorded in the region, including half of the endemic species recorded in that previous study.

Our results also demonstrate that a reduction in riparian forest cover has an effect on anuran species composition in both rivers. Riparian habitats can be used by amphibians for foraging, dispersal and reproduction, and the habitat size required to preserve some species is up to hundreds of meters (Semlitsch \& Bodie 2003, Ficetola et al. 2009). The removal of riparian vegetation can result in marked physical and structural changes in the river and on its margins (Gomi et al. 2006), and these changes generally cause a shift in amphibian species composition (Olson et al. 2007, Rodríguez-Mendoza \& Pineda 2010). The most abundant species in both rivers studied, $C$. brasiliensis, is a stream-dwelling amphibian typical of forested areas (MAIA-CARNEIro et al. 2012), that is classified as Near Threatened (IUCN 2012). It was comparatively more abundant in the portions of the rivers that have greater forest cover. On the other hand, some species that are typical of open areas (natural or anthropogenic), for instance Scinax alter (Lutz, 1973), were found only in the plots with lesser riparian vegetation. The riparian vegetation in portions of the rivers outside the REGUA forest was mostly surrounded by pastures, which allows the occupation of these areas by frog species adapted to disturbed habitats, such as some hylids and leptodactylids (Almeida-Gomes et al. 2008, 2010).

The value of riparian forests for the conservation of biodiversity and ecosystem services has already been recognized (Ricketts 2004, Lees \& Peres 2008, Mendenhall et al. 2014), yet few studies have ascertained the effect riparian forest removal on local communities. This study demonstrates that riparian forests maintain a diverse community of amphibians that is drastically different from the community next to riparian pastures. Species that are more adapted to disturbed areas can benefit from forest reduction, which may cause the changes in species composition observed in our analysis. Our results exemplify the potential consequences of the proposed changes' the Brazilian forest code: population reductions and local extinctions of frog species that depend on these riparian environments.

\section{ACKNOWLEDGMENTS}

Mauricio Almeida-Gomes received Post-Doctoral scholarship from Programa Nacional de Pós-Doutorado (PNPD-CAPES). This study was supported by research grants from CNPq (pro- cesses 304791/2010-5 and 472287/2012-5) and FAPERJ through Cientistas do Nosso Estado Program (process E-26/102.404.2009 and E-26/102.765.2012) to C. F. D. Rocha and from CNPq (processes 307961/2011-7) and FAPERJ through Cientistas do Nosso Estado Program (process E-26/102.765/2012) to M.V. Vieira. We thank Nicholas J. Locke of the Reserva Ecológica de Guapiaçu (REGUA) for logistical support during our fieldwork in that area and all colleagues who helped us with data collection.

\section{LITERATURE CITED}

Almeida-Gomes M, Rocha CFD (2014) Landscape connectivity may explain anuran species distribution in an Atlantic forest fragmented area. Landscape Ecology 29(1): 29-40. doi: 10.1007/s10980-013-9898-5

Almeida-Gomes M, Vrcibradic D, Siqueira CC, Kiefer MC, Klaion T, Almeida-Santos P, Nascimento D, Ariani CV, Borges-Júnior VNT, Freitas-Filho RF, Van Sluys M, Rocha CFD (2008) Herpetofauna of an Atlantic Rainforest area (Morro São João) in Rio de Janeiro State, Brazil. Anais da Academia Brasileira de Ciências 80(2): 291-300.

Almeida-Gomes M, Almeida-Santos M, Goyannes-Araújo P, BorgesJúnior VNT, Vrcibradic D, Siqueira CC, Ariani CV, Dias AS, Souza VV, Pinto RR, VAn Sluys M, Rocha CFD (2010) Anurofauna of an Atlantic Rainforest fragment and its surroundings in Northern Rio de Janeiro State, Brazil. Brazilian Journal of Biology 70(3): 871-877.

Almeida-Gomes M, Lorini ML, Rocha CFD, Vieira MV (2014a) Underestimation of extinction threat to stream-dwelling amphibians due to lack of consideration of narrow area of occupancy. Conservation Biology 28(2): 616-619. doi: 10.1111/cobi.12196

Almeida-Gomes M, Siqueira CC, Borges-Júnior VNT, Vrcibradic D, Fusinatto LA, Rocha CFD (2014b) Herpetofauna of the Reserva Ecológica de Guapiaçu (REGUA) and its surrounding areas, in the state of Rio de Janeiro, Brazil. Biota Neotropica 14(3): 1-15. doi: 10.1590/1676-0603007813

Báez S, Collins SL, Pockman WT, Johnson JE, Small EE (2012) Effects of experimental rainfall manipulations on Chihuahuan Desert grassland and shrubland plant communities. Oecologia 172(4): 1117-1127. doi: 10.1007/s00442-012-2552-0

Becker CG, Fonseca CR, Haddad CFB, Batista RF, Prado PI (2007) Habitat split and the global decline of amphibians. Science 318(5857): 1775-1777. doi: 10.1126/science. 1149374

Bell KE, Donnelly MA (2006) Influence of forest fragmentation on community structure of frogs and lizards in northeastern Costa Rica. Conservation Biology 20(6): 1750-1760. doi: 10.1111/j.1523-1739.2006.00522.x

CRump ML, Sсотt JR NJ (1994) Visual encounter surveys, p. 8492. In: Heyer WR, Donnely MA, Roy WM, Hayek LC, Foster MS (Eds) Measuring and Monitoring Biological Diversity: Standard Methods for Amphibians. Washington, DC, Smithsonian Institution Press, 384p. 
Ficetola GF, Padoa-Schioppa E, Bernardi F. (2009) Influence of landscape elements in riparian buffers on the conservation of semiaquatic amphibians. Conservation Biology 23(1): 114-123. doi: 10.1111/j.1523-1739.2008.01081.x

Gomi T, Sidle RC, Noguchi S, Negishi JN, Nik AR, SASAKi S (2006) Sediment and wood accumulations in humid tropical headwater streams: Effects of logging and riparian buffers. Forest Ecology and Management 224(1-2): 166-175. doi: 10.1016/j.foreco.2005.12.016

HADDAD CFB, PRADO CPA (2005) Reproductive modes in frogs and their unexpected diversity in the Atlantic Forest of Brazil. BioScience 55(3): 207-217.

Hof C, Araújo MB, Jetz W, Rahbeк C (2011) Additive threats from pathogens, climate and land-use change for global amphibian diversity. Nature 480: 516-519. doi: 10.1038/ nature 10650

IUCN (2012) Red list of Threatened Species. Version 2012.2. Available online at: www.iucnredlist.org [Accessed: 30 January 2013]

Keller A, Rödel M-O, Linsenmair E, Grafe TU (2009) The importance of environmental heterogeneity for species diversity and assemblage structure in Bornean stream frogs. Journal of Animal Ecology 78: 305-314. doi: 10.1111/ j.1365-2656.2008.01457.x

Lees AC, Peres CA (2008) Conservation value of remnant riparian forest corridors of varying quality for amazonian birds and mammals. Conservation Biology 22: 439-449. doi: 10.1111/j.1523-1739.2007.00870.x

Legendre P, Legendre L (1998) Numerical Ecology. Amsterdam, Elsevier, 853p.

Maia-Carneiro T, Dorigo TA, Almeida-Gomes M, Van Sluys M, RoCHA CFD (2012) Feedings habitats, microhabitat use, and daily activity of Cycloramphus brasiliensis (Anura: Cycloramphidae) from the Atlantic Rainforest, Brazil. Zoologia 29(3): 277-279. doi: 10.1590/S1984-46702012000300007

Mendenhall CD, Frishroff LO, Santos-Barrera G, Pacheco JS, Mesfun E, Quijano FM, Ehrlich PR, Ceballos G, Daily GC, Pringle RM (2014) Countryside biogeography of Neotropical reptiles and amphibians. Ecology 95: 856-870. doi: 10.1890/12-2017.1

Metzger JP, Lewinsohn TM, Joly CA, Verdade LM, Martinelli LA, Rodrigues RR (2010) Brazilian Law: full speed in reverse? Science 329: 276-277.

Submitted: 30 May 2014

Received in revised form: 10 August 2014

Accepted: 06 December 2014

Editorial responsibility: Mauricio O. Moura
Mittermeier RA, Gil RP, Hoffman M, Pilgrim J, Brooks T, Mittermeier CG, Lamoreux J, Fonseca GAB (2005) Hotspots revisited: earth's biologically richest and most endangered terrestrial ecoregions. Washington, DC, Conservation International, 392p.

Olson DH, Anderson PD, Frissel CA, Welsh Jr HH, Bradford DF (2007) Biodiversity management approaches for streamriparian areas: Perspectives for Pacific Northwest headwater forests, microclimates, and amphibians. Forest Ecology and Management 246: 81-107. doi:10.1016/j.foreco.2007.03.053

PARRIS KM, McCARTHY MA (1999) What influences the structure of frog assemblages at forest streams? Australian Journal of Ecology 24(5): 495-502. doi: 10.1046/j.1442-9993.1999.00989.x Ribeiro MC, Metzger JP, Martensen aC, Ponzoni FJ, Hirota MM (2009) The Brazilian Atlantic Forest: how much is left, and how is the remaining forest distributed? Implications for conservation. Biological Conservation 142: 1144-1156. doi:10.1016/j.biocon.2009.02.021

RICHARDS-ZAWACKI CL (2009) Effects of slope and riparian habitat connectivity on gene flow in an endangered Panamanian frog, Atelopus varius. Diversity and Ditributions 15: 796806. doi: 10.1111/j.1472-4642.2009.00582.x

RickETTS TH (2004) Tropical forest fragments enhance pollinator activity in nearby coffee crops. Conservation Biology 18(5): 1262-1271. doi: 10.1111/j.1523-1739.2004.00227.x

Rodríguez-Mendoza C, Pineda E (2010) Importance of riparian remnants for frog species diversity in a highly fragmented rainforest. Biology Letters 6: 781-784. doi: 10.1098/ rsbl.2010.0334

SEmLitsch RD, Bodie JR (2003) Biological criteria for buffer zones around wetlands and riparian habitats for amphibians and reptiles. Conservation Biology 17 (5): 1219-1228. doi: 10.1046/j.1523-1739.2003.02177.x

Todd BD, Luhring TM, Rothermel BB, GibBons W (2009) Effects of forest removal on amphibian migrations: implications for habitat and landscape connectivity. Journal of Applied Ecology 46: 554-561. doi: 10.1111/j.1365-2664.2009.01645.x

Zimmerman BL, BierregaArd RO (1986) Relevance of the equilibrium theory of island biogeography and species-area relations to conservation with a case from Amazonia. Journal of Biogeography 13 (2): 133-143. doi: 10.2307/ 2844988 